medRxiv preprint doi: https://doi.org/10.1101/2020.10.23.20218164; this version posted October 27, 2020. The copyright holder for this preprint

(which was not certified by peer review) is the author/funder, who has granted medRxiv a license to display the preprint in perpetuity.

It is made available under a CC-BY-ND 4.0 International license.

\title{
SARS-CoV-2 seroprevalence in healthcare workers of dedicated-COVID hospitals and non-COVID hospitals of District Srinagar, Kashmir
}

\author{
1.Muhammad Salim Khan \\ M.D Community Medicine
}

Affiliation: Department Of Community Medicine, Government Medical College, Srinagar, Kashmir, India

Email id:smsalimkhan2@gmail.com

2.Inaamul Haq

M.D Community Medicine

Affiliation: Department Of Community Medicine, Government Medical College, Srinagar, Kashmir, India

Email id:haqinaam@yahoo.co.in

3.Mariya Amin Qurieshi

M.D Community Medicine

Affiliation: Department Of Community Medicine, Government Medical College,

Srinagar, Kashmir, India

Email id: maryaamin123@gmail.com

4.Sabhiya Majid

Ph.D. Biochemistry 
Affiliation: Department Of Biochemistry, Government Medical College, Srinagar,

Kashmir, India

Emailid: zululubaba@gmail.com

5.Arif Akbar Bhat

Ph.D. Biochemistry

Affiliation: Department Of Biochemistry, Government Medical College, Srinagar, Kashmir, India

Emailid:ariefbhat19@gmail.com

6.Muhammad Obaid

M.D. Biochemistry

Affiliation: Department Of Biochemistry, Government Medical College, Srinagar, Kashmir, India

Emailid:obaid527@gmail.com

7.Tanzeela Bashir Qazi

P.G Scholar Community Medicine

Affiliation: Department Of Community Medicine, Government Medical College,

Srinagar, Kashmir, India

Email.id:qazitanzee@gmail.com

8.Iqra Nisar Chowdri

P.G Scholar, Community Medicine 
Affiliation: Department Of Community Medicine, Government Medical College,

Srinagar, Kashmir, India

Email.id:iqranisar92@gmail.com

9.Iram Sabah

P.G Scholar Community Medicine

Affiliation: Department Of Community Medicine, Government Medical College,

Srinagar, Kashmir, India

Email.id:iramsabah@yahoo.com

10.Misbah Ferooz Kawoosa

P.G scholar Community Medicine

Affiliation: Department Of Community Medicine, Government Medical College, Srinagar, Kashmir, India

Email.id:misbah.dps@gmail.com

11.Abdul Aziz Lone

P.G scholar Community Medicine

Affiliation: Department Of Community Medicine, Government Medical College, Srinagar, Kashmir, India

Email.id: loneaziz7@gmail.com

12.Shahroz Nabi

P.G Scholar Community Medicine 
Affiliation: Department Of Community Medicine, Government Medical College,

Srinagar, Kashmir, India

Email.id: dr.shahroznabi@gmail.com

\section{Ishtiyaq Ahmad Sumji}

P.G Scholar Community Medicine

Affiliation: Department Of Community Medicine, Government Medical College,

Srinagar, Kashmir, India

Email.id:dr.isumji@gmail.com

\section{Rafiya Kousar}

P.G Scholar Community Medicine

Affiliation: Department Of Community Medicine, Government Medical College, Srinagar, Kashmir, India

Email.id:rafia219@gmail.com

\section{Corresponding author}

Mariya Amin Qurieshi

M.D Community Medicine

Affiliation: Department Of Community Medicine, Government Medical College, Srinagar, Kashmir, India

Email id: maryaamin123@gmail.com

Orcid id:0000-0002-3217-3534

Running title: SARS-CoV-2 Seroprevalence among healthcare workers in Srinagar 
medRxiv preprint doi: https://doi.org/10.1101/2020.10.23.20218164; this version posted October 27, 2020. The copyright holder for this preprint (which was not certified by peer review) is the author/funder, who has granted medRxiv a license to display the preprint in perpetuity.

It is made available under a CC-BY-ND 4.0 International license .

\begin{abstract}
Background and objective: SARS-CoV-2 infection poses tremendous challenge to the healthcare system of nations across the globe. Serological testing for SARS-CoV-2 infection in healthcare workers, which form a high-risk group, helps in identifying the burden of hidden infection in an institutional setting.

Methods: We present the results of a cross-sectional serosurvey in healthcare workers from two different hospital settings based on their role in the management of SARS-CoV-2 patients in District Srinagar, Kashmir. In addition to testing for the presence of SARS-CoV-2 specific IgG, we collected information on influenza-like symptoms in the last four weeks and the status of RTPCR testing. SARS-CoV-2 specific IgG antibodies were detected in serum samples using a sensitive and specific chemiluminescent microparticle immunoassay technology.
\end{abstract}

Interpretation and Conclusion: Of 2915 healthcare workers who participated in the study, we analysed data from 2905 healthcare workers. The overall prevalence of SARS-CoV-2 specific IgG antibodies was $2.5 \%$ (95\% CI 2.0-3.1) in the healthcare workers of District Srinagar. Healthcare workers who had ever worked at a dedicated-COVID hospital had a substantially lower seroprevalence of $0.6 \%$ (95\% CI: $0.2-1.9)$. Among healthcare workers who had tested positive for RT-PCR, seroprevalence was $27.6 \%$ (95\% CI: 14.0 - 47.2). The seroprevalence of SARS-CoV-2 infection in healthcare workers of District Srinagar is low, reflecting that a high proportion of healthcare workers are still susceptible to the infection. It is crucial to lay thrust on infection prevention and control activities and standard hygiene practices by the healthcare staff to protect them from acquiring infection within the healthcare setting.

Keywords: SARS-CoV-2; Immunoglobulin G; Prevalence; Healthcare workers 


\section{Introduction}

India is emerging as the world's biggest hotspot for severe acute respiratory syndrome coronavirus 2 (SARS-CoV-2) infection, second only to the United States of America, with more than four million recorded infections in seven months following the first reported case on $30^{\text {th }}$ January $2020[1,2]$. Kashmir, a northern territory of India, reported its first positive case of novel coronavirus on $18^{\text {th }}$ March 2020 from a central district Srinagar which is currently the most affected place within the territory from where presently more than $20 \%$ of new cases are reported each day[3]. In addition to three tertiary care hospitals, one District Hospital, and twoSub-district Hospitals in District Srinagar, Primary Health Centres sizeably caters to the healthcare needs of the people. They are playing a pivotal role in the current pandemic for containment of SARS-CoV-2 infection. The healthcare workers, because of their job profile, are at a higher risk of acquiring SARS-CoV-2 infection[4-6]. As the proportion of individuals with asymptomatic infection is relatively high and variable across different regions, there is growing evidence which suggests that this hidden pool is serving as a potential source of infection for the general population and health care workers do not behave differently[7, 8].

Many countries have started testing for the presence of antibodies against SARS-CoV-2 infection, both at the population level and in specific groups like healthcare workers. Seroepidemiological studies are crucial in understanding the dynamics of SARS-CoV-2 infection. Seroepidemiological studies have been conducted in many places among the general population, but there is insufficient data on healthcare workers. World Health Organisation, in its scientific briefing on $24^{\text {th }}$ April, encouraged the member states to conduct seroepidemiological studies in the context of coronavirus disease (COVID-19) for a better understanding of the extent of infection[9-11]. 
medRxiv preprint doi: https://doi.org/10.1101/2020.10.23.20218164; this version posted October 27, 2020. The copyright holder for this preprint (which was not certified by peer review) is the author/funder, who has granted medRxiv a license to display the preprint in perpetuity.

It is made available under a CC-BY-ND 4.0 International license .

Therefore, to find out the prevalence of SARS-CoV-2 infection among healthcare workers, we undertook this seroepidemiological study by testing for SARS-CoV-2 specific IgG to get an insight into the extent of infection among healthcare workers in our setting.

\section{Material and Methods}

\section{Study design and settings}

We conducted this seroepidemiological study to find out the presence of $\operatorname{IgG}$ antibodies against SARS-CoV-2 among healthcare workers of District Srinagar, Kashmir. We commenced the data collection from $15^{\text {th }}$ June 2020 and completed it in two weeks. As a part of the preparedness of the health system for the pandemic, the central Ministry of Health and Family Welfare of the country specified guidelines for health facilities for the management of COVID-19 cases. Thus, hospitals were categorized into dedicated-COVID hospitals and non-COVID hospitals. Dedicated-COVID hospitals provide comprehensive care to COVID-19 patientsexclusively, with round the clock facility of fully functional intensive care units, ventilators, and beds with assured oxygen support [12].

\section{Participants}

We invited healthcare workers from threededicated-COVID, seven non-COVID tertiary care hospitals, two sub-district hospitals, and four primary health centresacross the District (Figure 1). Administrative heads of the hospitals received written communication for permission to conduct the study and invite all healthcare workers in their hospitals for participation.

Participation in the study was also encouraged through use of social media and word of mouth.

All frontline healthcare workers, including doctors, administrative and laboratory personnel, technicians, field workers who were involved in surveillance activity, and other supporting staff, were part of the study. The participation of healthcare workers in the survey was voluntary. 
medRxiv preprint doi: https://doi.org/10.1101/2020.10.23.20218164; this version posted October 27, 2020. The copyright holder for this preprint (which was not certified by peer review) is the author/funder, who has granted medRxiv a license to display the preprint in perpetuity.

It is made available under a CC-BY-ND 4.0 International license .

\section{Procedure}

We gathered all the information on a form generated on mobile phones using Epicollect5, a free mobile phone data gathering tool widely used in public health research for the collection of large scale data[13].Doctors, specifically trained in the use of Epicollect5, conducted the interviews. We collected information about the participants' role in the current pandemic in terms of their involvement in providing care to COVID-19 patients. Participants also provided information on risk factors for SARS-CoV-2 infection (history of travel since $1^{\text {st }}$ January 2020 , flu-like symptoms in the last four weeks). Following the interview, trained phlebotomists collected $3-5 \mathrm{~mL}$ of venous blood under aseptic precautions. Centrifugation of the samples was done at the facility. The centrifuged samples were transported to a central laboratory for further processing and testing. Centrifugation was done at the central laboratory for sites that did not have the facility. Standard operating procedures were strictly adhered to during collection, transportation, and testing of blood samples.

\section{Variables}

Our primary outcome of interest was the presence of $\mathrm{IgG}$ antibodies against SARS-CoV-2 among healthcare workers.

\section{Laboratory procedure}

We used a chemiluminescent microparticle immunoassay (CMIA) based procedure for the detection of SARS-CoV-2 specific IgG antibodies in serum samples. We followed the manufacturer's recommendations for the process. The assay is an automated, two-step immunoassay for the qualitative detection of IgG antibodies to SARS-CoV-2 in human serum and plasma. The test result was considered positive for SARS-CoV-2 IgG if the 'index value' was $\geq 1.4$ as provided by the manufacturer[14].

Laboratory data was entered in a similar fashion using Epicollect5. Two trained persons independently entered the laboratory results in two separate forms.Data from the two forms were 
medRxiv preprint doi: https://doi.org/10.1101/2020.10.23.20218164; this version posted October 27, 2020. The copyright holder for this preprint

checked for any discrepancies, in which case, the source data was referred to for necessary corrections. The information gathered during the interview and the laboratory results were linked with the help of a unique identification number, which was generated at the time of the interview.

\section{Statistical analysis}

We estimated the proportion and 95\% confidence interval for the SARS-CoV-2 specific IgG antibody in healthcare workers. We looked for the difference in seroprevalence across gender, age group, specific occupation group, and type of health facility (dedicated-COVID hospital versus non-COVID hospital). Seroprevalence was also estimated separately for healthcare workers who reported symptoms in the last four weeks, had a history of exposure to a known case of SARS-CoV-2 positive patient, or had undergone testing by reverse transcriptasepolymerase chain reaction (RT-PCR). We used the Chi-square test to report two-sided p-values for comparison of seroprevalence between groups. The exact test was used instead of the Chisquare test when the expected frequency was less than five in more than $20 \%$ of the cells. We did not adjust p-values for multiple comparison. Stata version 15.1 was used for data analysis.

\section{Ethics approval and consent to participate}

The Institutional Ethics Committee of Government Medical College Srinagar approved the study (Ref. No. 1003/ETH/GMC dated 13-05-2020). We obtained written, informed consent from all participants.

\section{Results}

Out of 7346 healthcare workers in the District 2915 participated in the study. The overall response rate was $40 \%, 47 \%$ among doctors, and $37 \%$ among paramedical and other hospital staff. We analysed the information gathered from 2905 healthcare workers. The information on the Epicollect5 interview form was missing for nine individuals, and the laboratory report was 
missing for one. The mean age of the participants was 38.6 years, and $35.8 \%$ were females. One third $(33.8 \%)$ of the participants were doctors, of whom nearly half were resident doctors. (Table 1)

Table 1: Seroprevalence of SARS-CoV-2 specific IgG antibodies across baseline characteristics of healthcare workers

Of the 2905 healthcare workers, 123 (4.2\%) reported an influenza-like illness(fever and cough) in the four weeks preceding the interview, and 339 (11.7\%) reported having close contact with a coronavirus disease (COVID-19) case. Seven hundred sixty (26.2\%) healthcare workers had taken an RT-PCR, and out of these, 29 (3.8\%) had a positive test result. (Table 2)

Table 2: Seroprevalence of SARS-CoV-2 specific IgG antibodies by clinical characteristics and specific risk factors

We reported an overall seroprevalence of 2.5\% (95\% CI 2.0-3.1) for SARS-CoV-2 specific IgG antibodies among the healthcare workers of District Srinagar. Seropositivity was not significantly related to age, gender, or occupation group of healthcare workers. (Table 1)

We found a significantly higher seropositivity rate among those with a history of influenza-like illness ( $\mathrm{p}<0.001)$, a history of positive RT-PCR $(\mathrm{p}<0.001)$, ever put under quarantine $(\mathrm{p}=0.009)$, and those with a self-reported history of close contact with a COVID-19 case ( $\mathrm{p}=0.014)$.

Surprisingly, healthcare workers who had ever worked at a dedicated-COVID hospital had a low prevalence of infection in comparison to those who never worked at a facility dedicated to such patients $(\mathrm{p}=0.004)$. 


\section{Discussion}

We aimed to estimatethe seroprevalence of SARS-CoV-2 infection in healthcare workers working in different hospital settings of District Srinagar, Kashmir. In general, seroprevalence was low (2.5\%), with little difference across gender or occupation group.

Seroprevalence studies done in healthcare workers in different settings have revealed varied findings with estimates ranging from $1 \%$ to $10.2 \%[15-18]$. Generally speaking, the seroprevalence among healthcare workers is not disproportionate when compared to the general population, which reflects the different dynamics of this infection when compared to other infections in healthcare settings. The low seroprevalence observed in our study coincides with the overall low infection rate in the population. During the study period, the District reported a median daily number of new infections of 28 (IQR 17-46), which is indicative of the early phase of the pandemic in the population at the time of study[19].

Among the healthcare worker occupation groups, ambulance drivers, and housekeeping staff of the hospitals reported the highest seroprevalence. The possible explanation could be a lower level of standard hygiene practices and inadequate use or reuse of protective gear due to a shortage of personal protective equipment and lack of training on donning and doffing of personal protective equipment[20].

Interestingly, healthcare workers who were working in a dedicated-COVID hospitals or had ever worked there had a very low seroprevalence, $0.6 \%$ (95\%CI 0.2-1.9). As these facilities were dedicated to the management and care of SARS-CoV-2 patients, the hospital staff was taking extreme precautions while providing care to these patients. These hospitals were on high alert and were strictly adhering to infection prevention and control practices. Secondly, being a potentially high-risk area for transmission of infection, these facilities did staff rationing to reduce the duration of exposure in the healthcare staff. Staff from other hospitals, which included resident doctors, nurses, and other support staff, were put on rotational duty at the 
medRxiv preprint doi: https://doi.org/10.1101/2020.10.23.20218164; this version posted October 27, 2020. The copyright holder for this preprint

dedicated-COVID hospitals to compensate for the additional requirement. We did not, however, ascertain the adherence to infection prevention and control guidelines in the two different categories of hospitals. Based on the level of exposure in healthcare workers of University Hospital in Germany, Kortha $\mathbf{J}$ et al. reported a lower seroprevalence in the high-risk group, which included hospital staff who come in daily contact with SARS-CoV-2 patients and work in intensive care units[16].

We report a two-fold higher seroprevalence $(4.4 \%)$ in healthcare workers who reported close contact with a SARS-CoV-2 positive patient as compared to those who did not report any such contact. Respiratory infections pose a greater health risk in an occupational setting to healthcare workers. There is no classic literature available that has established the risk factors for transmission for the SARS-CoV-2 infection. So far, globally,among thousands of healthcare workers infected with SARS-CoV-2 infection, close contact with a SARS-CoV-2 patient has been identified as one of the leading risk factors, among others which include lack of personal protective equipment, poor infection prevention and control practices, work overload, and preexisting health condition[21].

The seroprevalence estimates in healthcare workers who reported symptoms suggestive of SARS-CoV-2 infection in the preceding four weeks was $12.2 \%$,suggesting the presence of other circulating respiratory pathogens that give rise to these symptoms.

Among those who reported a previously positive RT-PCR for SARS-CoV-2, only $27.6 \%$ showed the presence of SARS-CoV-2 specific IgG antibodies. The inability to mount an antibodymediated immune response or early conversion to seronegative status during the convalescence phase has been suggested[22]. On the contrary, seropositivity in previously negative RT-PCR subjects was $1.9 \%$. There are few plausible explanations for such observations. Firstly, several studies have reported 2\%-29\% false-negative results from RT-PCR[23-25]. Secondly, the sensitivity of the SARS-CoV-2 assay is influenced by the timing of test post symptoms or RTPCR positivity. The sensitivity of the test assay we used varies from $53.1 \%$ at day- 7 to $100 \%$ at 
medRxiv preprint doi: https://doi.org/10.1101/2020.10.23.20218164; this version posted October 27, 2020. The copyright holder for this preprint

day-17 post-infection[26].Variable viral load and difference in duration of viral shedding are the other possible reasons for false-negative RT-PCR[27, 28].

In our study, seroconversion among asymptomatic healthcare workers who tested positive on RT-PCR was $20.8 \%$. Among healthcare workers who reported influenza-like illness and were RT-PCR positive, seropositivity was $60 \%$. In a study from a Medical University Hospital in China, $40 \%$ and $13 \%$ asymptomatic and symptomatic SARS-CoV-2 positive cases, respectively, became seronegative, after initial seropositivity, eight weeks after hospital discharge[29].

Serological testing gives an insight into the immune status of the healthcare workers against SARS-CoV-2 infection. However, it is premature to conclude that those who have developed antibodies against the infection are risk-free or protected against reinfection. As the epidemic progresses, more and more healthcare workers are likely to get infected. Serial cross-sectional serosurveys can helpin monitoring the progression of the pandemic within a healthcare setting and guide the hospital authorities in resource allocation.

\section{Strengths}

We used Abbott Architect SARS-CoV-2 IgG assay, which has exhibited a high level of consistency and performance characteristics when tested on the different patient populations.

The participation rate was reasonably good in our study, and we included all the major hospitals in the District. The findings from our study could be considered as being representative of the healthcare workers in the District.

\section{Limitations}

We did not collect information on the timing of symptoms and the date at which the healthcare workers became RT-PCR positive.With a cross-sectional study design, we cannot ascertain the reconversion from initial $\mathrm{IgG}$ positive to $\mathrm{IgG}$ negative status, which warrants a cohort study. Participation in the survey was voluntary. There is thus a possibility of selection bias. Some healthcare workers with recent exposure or those who were symptomatic at the time of the study 
might not have participated, thinking that they would not benefit by IgG testing in the early phase of infection.

\section{Conclusions}

We conclude that the seroprevalence of SARS-CoV-2 infection was low among the healthcare workers of District Srinagar at the time of the study. Healthcare workers in a dedicated-COVID hospital or who had ever worked in such a facility had lower seroprevalence suggesting adherence to standard operating procedures while dealing with SARS-CoV-2 patients. It is crucial to lay thrust on infection prevention and control activities in the hospital settings. Training and re-training of sanitation and other housekeeping staff about standard hygienic practices and appropriate use of the protective gear are needed.

\section{List of abbreviations}

SARS-CoV-2: Severe acute respiratory syndrome coronavirus 2; COVID-19: Coronavirus disease; CMIA: Chemiluminescent microparticle immunoassay; CI: Confidence interval.

Data Availability statement: Data shall be made available on request through corresponding author.

\section{Conflict of interest}

Authors declare that they have no competing interests

\section{Funding statement}

The study received mainly institutional funding from Government Medical College Srinagar with support from District Disaster Management Authority Srinagar. The funding bodies have no role in design, collection, analysis, interpretation, or writing of manuscript.

\section{Acknowledgments}


medRxiv preprint doi: https://doi.org/10.1101/2020.10.23.20218164; this version posted October 27, 2020. The copyright holder for this preprint (which was not certified by peer review) is the author/funder, who has granted medRxiv a license to display the preprint in perpetuity.

It is made available under a CC-BY-ND 4.0 International license .

We are thankful to Principal and Dean Government Medical College, Srinagar, Professor Samia Rashid, and District Commissioner, Srinagar, Shahid Iqbal Chowdhary for their support. We acknowledge the support rendered by the Directorate of Health Services, Kashmir, Chief Medical Officer, Srinagar, Block Medical Officers, and Zonal Medical Officers of District Srinagar, Kashmir. We highly appreciate the efforts put in by medical interns in data collection and laboratory in-charge Gulzar Ahmad Wani, Ph.D. scholar, Biochemistry, and his staff, who were involved in this study. We thank the study participants for understanding the importance of this study and giving their time and consent for participation.

\section{References}

1. MoHFW | Home. https://www.mohfw.gov.in/. Accessed 9 Sep 2020.

2. Coronavirus Outbreak in India - covid19india.org. https://www.covid19india.org/. Accessed 9 Sep 2020.

3. Govt. of Jammu \& Kashmir, Director Of Information \& Public Relations $\square::$ News

Description. http://new.jkdirinf.in/NewsDescription.aspx?ID=66598. Accessed 9 Sep 2020.

4. Black JRM, Bailey C, Przewrocka J, Dijkstra KK, Swanton C. COVID-19: the case for health-care worker screening to prevent hospital transmission. The Lancet. 2020;395:1418-20. doi:10.1016/S0140-6736(20)30917-X.

5. Nguyen LH, Drew DA, Graham MS, Joshi AD, Guo C-G, Ma W, et al. Risk of COVID-19 among front-line health-care workers and the general community: a prospective cohort study. Lancet Public Heal. 2020;5. doi:10.1016/s2468-2667(20)30164-X.

6. The Lancet. COVID-19: protecting health-care workers. The Lancet. 2020;395:922. doi:10.1016/S0140-6736(20)30644-9.

7. Byambasuren O, Cardona M, Bell K, Clark J, McLaws M-L, Glasziou P. Estimating the 
extent of asymptomatic COVID-19 and its potential for community transmission: systematic review and meta-analysis. medRxiv. 2020;:2020.05.10.20097543.

doi:10.1101/2020.05.10.20097543.

8. Rosenbaum L. Facing covid-19 in Italy - Ethics, logistics, and therapeutics on the epidemic's front line. New England Journal of Medicine. 2020;382:1-3.

doi:10.1056/NEJMp2005492.

9. Unity Studies: Early Investigation Protocols.

https://www.who.int/emergencies/diseases/novel-coronavirus-2019/technical-guidance/earlyinvestigations. Accessed 9 Sep 2020.

10. Pollán M, Pérez-Gómez B, Pastor-Barriuso R, Oteo J, Hernán MA, Pérez-Olmeda M, et al. Prevalence of SARS-CoV-2 in Spain (ENE-COVID): a nationwide, population-based seroepidemiological study. Lancet. 2020;396:535-44. doi:10.1016/S0140-6736(20)31483-5.

11. Folgueira MD, Munoz-Ruiperez C, Alonso-Lopez MA, Delgado R. SARS-CoV-2 infection in Health Care Workers in a large public hospital in Madrid, Spain, during March 2020. medRxiv. 2020; March:2020.04.07.20055723. doi:10.1101/2020.04.07.20055723.

12. Guidance document on appropriate management of suspect/confirmed cases of COVID-19. https://www.mohfw.gov.in/pdf/FinalGuidanceonMangaementofCovidcasesversion2.pdf. Accessed 9 Sep 2020.

13. Epicollect5 - Free and easy-to-use mobile data-gathering platform. https://five.epicollect.net/. Accessed 9 Sep 2020.

14. SARS-CoV-2 Immunoassay | Abbott Core Laboratory. https://www.corelaboratory.abbott/us/en/offerings/segments/infectious-disease/sars-cov-2. Accessed 9 Sep 2020.

15. Bendavid E, Mulaney B, Sood N, Shah S, Ling E, Bromley-Dulfano R, et al. COVID-19 
medRxiv preprint doi: https://doi.org/10.1101/2020.10.23.20218164; this version posted October 27, 2020. The copyright holder for this preprint (which was not certified by peer review) is the author/funder, who has granted medRxiv a license to display the preprint in perpetuity.

It is made available under a CC-BY-ND 4.0 International license .

Antibody Seroprevalence in Santa Clara County, California. medRxiv.

$2020 ;: 2020.04 .14 .20062463$. doi:10.1101/2020.04.14.20062463.

16. Korth J, Wilde B, Dolff S, Anastasiou OE, Krawczyk A, Jahn M, et al. SARS-CoV-2specific antibody detection in healthcare workers in Germany with direct contact to COVID-19 patients. J Clin Virol. 2020;128. doi:10.1016/j.jcv.2020.104437.

17. Steensels D, Oris E, Coninx L, Nuyens D, Delforge ML, Vermeersch P, et al. Hospital-Wide SARS-CoV-2 Antibody Screening in 3056 Staff in a Tertiary Center in Belgium. JAMA Journal of the American Medical Association. 2020;324:195-7. doi:10.1001/jama.2020.11160.

18. Behrens GMN, Cossmann A, Stankov M V., Witte T, Ernst D, Happle C, et al. Perceived versus proven SARS-CoV-2-specific immune responses in health-care professionals. Infection. 2020;48:631-4. doi:10.1007/s15010-020-01461-0.

19. Statistics | CovidKashmir. https://covidkashmir.org/statistics. Accessed 9 Sep 2020.

20. Rational use of personal protective equipment for coronavirus disease (COVID-19) and considerations during severe shortages. https://www.who.int/publications/i/item/rational-use-ofpersonal-protective-equipment-for-coronavirus-disease-(covid-19)-and-considerations-duringsevere-shortages. Accessed 9 Sep 2020.

21. Mhango M, Dzobo M, Chitungo I, Dzinamarira T. COVID-19 Risk Factors Among Health Workers: A Rapid Review. Safety and Health at Work. 2020.

22. Immune responses and immunity to SARS-CoV-2. https://www.ecdc.europa.eu/en/covid19/latest-evidence/immune-responses. Accessed 9 Sep 2020.

23. Arevalo-Rodriguez I, Buitrago-Garcia D, Simancas-Racines D, Zambrano-Achig P, del Campo R, Ciapponi A, et al. False-negative results of initial RT-PCR assays for COVID-19: a systematic review. medRxiv. 2020;:2020.04.16.20066787. doi:10.1101/2020.04.16.20066787. 
medRxiv preprint doi: https://doi.org/10.1101/2020.10.23.20218164; this version posted October 27, 2020. The copyright holder for this preprint

(which was not certified by peer review) is the author/funder, who has granted medRxiv a license to display the preprint in perpetuity.

It is made available under a CC-BY-ND 4.0 International license .

24. Ai T, Yang Z, Hou H, Zhan C, Chen C, Lv W, et al. Correlation of Chest CT and RT-PCR

Testing for Coronavirus Disease 2019 (COVID-19) in China: A Report of 1014 Cases.

Radiology. 2020;296:E32-40. doi:10.1148/radiol.2020200642.

25. Woloshin S, Patel N, Kesselheim AS. False Negative Tests for SARS-CoV-2 Infection -

Challenges and Implications. N Engl J Med. 2020;383:e38. doi:10.1056/NEJMp2015897.

26. Bryan A, Pepper G, Wener MH, Fink SL, Morishima C, Chaudhary A, et al. Performance characteristics of the abbott architect sars-cov-2 igg assay and seroprevalence in Boise, Idaho. $\mathrm{J}$ Clin Microbiol. 2020;58. doi:10.1128/JCM.00941-20.

27. Long QX, Liu BZ, Deng HJ, Wu GC, Deng K, Chen YK, et al. Antibody responses to SARS-CoV-2 in patients with COVID-19. Nat Med. 2020;26:845-8. doi:10.1038/s41591-0200897-1.

28. Tahamtan A, Ardebili A. Real-time RT-PCR in COVID-19 detection: issues affecting the results. Expert Review of Molecular Diagnostics. 2020;20:453-4.

doi:10.1080/14737159.2020.1757437.

29. Long QX, Tang XJ, Shi QL, Li Q, Deng HJ, Yuan J, et al. Clinical and immunological assessment of asymptomatic SARS-CoV-2 infections. Nat Med. 2020;26:1200-4.

doi:10.1038/s41591-020-0965-6. 
medRxiv preprint doi: https://doi.org/10.1101/2020.10.23.20218164; this version posted October 27, 2020. The copyright holder for this preprint (which was not certified by peer review) is the author/funder, who has granted medRxiv a license to display the preprint in perpetuity. It is made available under a CC-BY-ND 4.0 International license.

Table I: Seroprevalence of SARS-CoV-2 specific IgG antibodies across baseline characteristics of healthcare workers

$\begin{array}{ll}\text { Number of } & \text { Seroprevalence }(95 \% \\ \text { participants } & \text { Confidence Interval) }\end{array}$

\section{Overall}

2905

$2.5 \%(2.0-3.1)$

Gender

0.347

Male

1865

$2.7 \%(2.0-3.5)$

Female

1040

$2.1 \%(1.4-3.2)$

Age (years)

0.186

$<30$

705

$3.4 \%(2.3-5.0)$

$30-49$

1612

$2.2 \%(1.6-3.1)$

$\geq 50$

588

$2.0 \%(1.2-3.6)$

\section{Occupation group}

Doctors

980

$2.8 \%(1.9-4.0)$

Nurses

321

$2.8 \%(1.5-5.3)$

Medical

Technician $^{*}$

397

$2.5 \%(1.4-4.6)$

Pharmacist

109

$0 \%$

Field staff ${ }^{\dagger}$

141

$0 \%$

Ambulance

57

$3.5 \%(0.9-13.3)$

drivers

\section{Hospital}

Sanitation

624

$2.4 \%(1.5-4.0)$

staff

Other

housekeeping 
staff

Designation of

doctors

Administration

Faculty

doctors $^{*}$

Intern

Medical

officer- PHC

Resident

doctors $^{\S}$

\section{Specialty of doctors}

Critical care

Medical

Surgical

Non- clinical

MBBS
61

274

58

130

457

57

327

138

115
$3.3 \%(0.8-12.5)$

$1.1 \%(0.4-3.4)$

$3.4 \%(0.8-13.1)$

$2.3 \%(0.7-7.0)$

$3.7 \%(2.3-5.9)$
$1.8 \%(0.2-11.9)$

$3.5 \%(2.0-6.1)$

$3.7 \%(2.1-6.4)$

$0.7 \%(0.1-5.0)$

$0.9 \%(0.1-6.0)$

*Medical Technicians include persons who handle sophisticated equipment and have expertise in working in different areas like laboratories of biochemistry/pathology/microbiology/blood bank, operation theatre, ophthalmology, radiology

${ }^{\dagger}$ Field staff include Female Multipurpose Health Workers, Community Health Officers, Accredited Social Health Activists, Health Visitors

${ }^{\ddagger}$ Faculty doctors participate mainly in teaching, research, administration, as well as in clinical care based on their field of expertise

${ }^{\S}$ Residents are doctors who are receiving postgraduate training in a particular specialty 
Table II: Seroprevalence of SARS-CoV-2 specific IgG antibodies by clinical characteristics and specific risk factors

$\begin{array}{lll}\text { Number of } & \text { Seropositivity (95\% } & \text { p-value } \\ \text { participants } & \text { CI) } & \end{array}$

Symptoms of an

$<0.001$

influenza-like illness

Present

Absent

RT-PCR status

Ever done

Never done

RT-PCR result $(n=760)$

Positive

Negative

Ever put under

quarantine

Yes

No

2637

Ever worked at a

quarantine centre

Yes

60

2845

No
0.390

$2.9 \%(1.9-4.4)$

$2.3 \%(1.8-3.1)$

$<0.001$

29

$27.6 \%(14.0-47.2)$

$1.9 \%(1.1-3.2)$

0.009

$4.9 \%(2.8-8.2)$

$2.2 \%(1.7-2.9)$

Ever worked in a

0.004

\section{hospital}


medRxiv preprint doi: https://doi.org/10.1101/2020.10.23.20218164; this version posted October 27, 2020. The copyright holder for this preprint (which was not certified by peer review) is the author/funder, who has granted medRxiv a license to display the preprint in perpetuity. It is made available under a CC-BY-ND 4.0 International license.

Yes

No

History of close contact

with a COVID-19 case

Yes

No

January 2020

Yes

No

${ }^{*}$ A history of fever and cough with or without other symptoms, within four weeks preceding the date of interview

Fig I: Health facilities in District Srinagar and the number of hospitals selected for the study

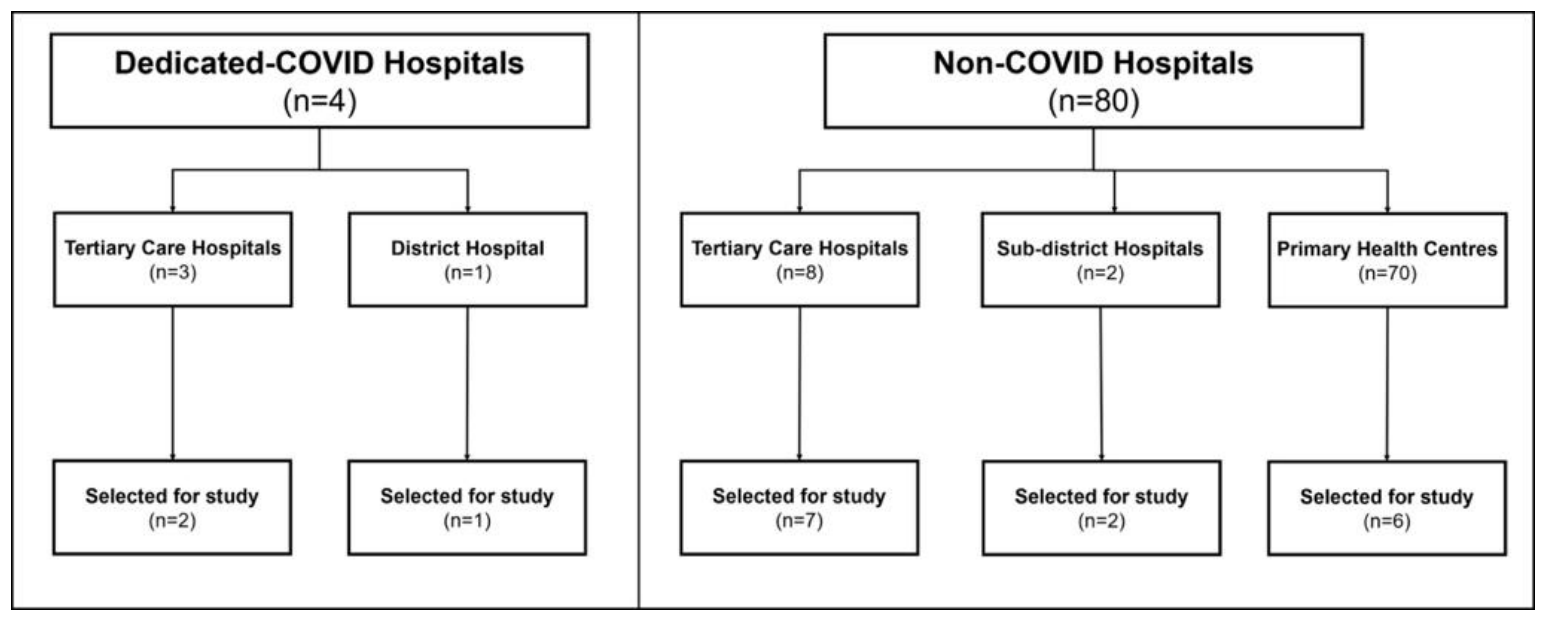

